\title{
Bending Creep of Glulam and Bolted Glulam under Changing Relative Humidity ${ }^{1}$
}

\author{
Junchul PARK ${ }^{2} \cdot$ Yojin $\mathrm{SONG}^{3} \cdot$ Soonil HONG (D)
}

\begin{abstract}
This study was carried out in order to evaluate the bending creep deflection of glulams and bolted glulams beam-to-beam connection with steel-gusset plates and bolts under changing relative humidity. The two types of glulam beams (130 $\mathrm{mm}$ in width, $175 \mathrm{~mm}$ in thickness, and $3000 \mathrm{~mm}$ in length) used in this study were made from domestic larch and composed of seven layers. The gussets were made of 8-mm-thick steel plates. Creep testing was conducted under constant loads in an uncontrolled environment. The test was carried out in a room that was well ventilated through a window. The creep test specimens were loaded for 33,000 hours. A bending creep test for the glulams was conducted through four-point loading. The applied stresses were $20 \%$ and $30 \%$ of the MOR in the static bending test for the glulam and bolted glulam, respectively. After 33,000 hours, the creep deflection of the glulam at a $20 \%$ stress level increased by $39 \%$ to $99 \%$, while the creep deflection of the glulam at a $30 \%$ stress level increased by $27 \%$ to $67 \%$, as compared with instantaneous elastic deflection. The relative creep increased during autumn and winter, and recovered during spring and summer. The relative creep of the bolted glulams was changed abruptly by loading up to 5,000 hours, but stabilized after 5,000 hours, and then gradually increased until 33,000 hours. The relative creep of the bolted glulam increased 2.11 times on average after 33,000 hours.
\end{abstract}

Keywords: glulam, bolted glulam, bending creep, relative creep, mechano-sorptive

\section{INTRODUCTION}

The main performance required for the beams in buildings constructed using the column-beam method is to withstand the expected vertical load during the period of use. In this case, structural-sized lumbers are evaluated by applying an external force within a short period of time in a static strength test. However, the deformation behavior of the flexural member during the application of a long-term external force is also very important in terms of the reliability of the building structure (Byeon et al., 2017). For hydrophilic timbers, the moisture absorption and desorption have a significant effect on strength property and dimensional deformation. Therefore, the creep phenomenon should be considered in structural design by using viscoelastic timbers that are not completely elastic (Epmeier et al., 2007). In South Korea, where the temperature and hu-

${ }^{1}$ Date Received June 25, 2020, Date Accepted August 21, 2020

2 Production Management Team, KOAS CO. LTD., Paju-si 10858, Republic of Korea

${ }^{3}$ Department of Forest Biomaterials and Engineering, College of Forest and Environmental Sciences, Kangwon National University, Chuncheon 24341, Republic of Korea

$\dagger$ Corresponding author: Soonil HONG (e-mail: hongsi@kangwon.ac.kr ORCID: 0000-0002-9627-2208) 
midity variations are mostly due to the distinct seasonal changes, it is deemed necessary to conduct further research on mechano-sorptive behavior, which causes deflection of members by the interaction between stress and moisture content. Mechano-sorptive behavior has been the focus of many studies because it can increase deflection and result in early failure of timber beams. Many researchers have attempted to investigate the variables about mechano-sorption and the effects on creep behavior.

Hunt (1991) raised a question about the importance of relative humidity variation and suggested that the change rate of relative humidity could be important in mechano-sorptive creep. Bengtsson (2001) investigated the factors that influence mechano-sorptive creep, such as timber density, modulus of elasticity, fiber slope, and annual ring width, and found that the modulus of elasticity is the best parameter for predicting the relative creep. Bengtsson and Kliger (2003) conducted a creep test for Norway spruce according to the drying temperature. As a result, the timber dried at a high temperature $\left(115{ }^{\circ} \mathrm{C}\right)$ and showed a $30 \%$ smaller creep deformation than the timber dried at a low temperature $\left(70{ }^{\circ} \mathrm{C}\right)$. Furthermore, it was less affected by the moisture cycles. Aratake et al. (2011) conducted a bending creep test for the glulams manufactured differently depending on the composition of the Japanese Sugi and Douglas fir timbers, which have a very low modulus of elasticity. They reported that the bending creep showed opposite trends for the outer-layer timbers with large and small moduli of elasticity, regardless of the modulus of elasticity of the middle-layer timber. Ranta-Maunus and Kortesmaa (2000) researched on whether wood-based materials, such as glulams, could resist creep by surface coating. The creep tests were performed for seven to eight years in two environments: an environment where the temperature and humidity change under a low load, and a heated environment. As a result, the creep of wood-based materials progressed continuously and slowly, showing a high dependence on surface coating. The durations and moisture cycles of the creep test vary greatly according to the literature. O'Ceallaigh et al. (2014) reported that the wood specimens must be adjusted in accordance with the equilibrium moisture content in a new environmental condition during the creep test in order to produce the mechano-sorptive effect. For this reason, they suggested that the test must be conducted for a duration that allows sufficient observation of the moisture cycle because a short moisture cycle offers inaccurate result about the mechano-sorptive effect of timber.

Meanwhile, the increase of the beam span is inevitable with the increase in the number of large timber structures. The most basic solution for this is to extend the length of the members by applying connections between the beams. The most representative method of longitudinal joining of glulams is to put a metal plate, such as steel plate or gusset, on the outside of a member or insert it into a member and fix it with a metal fastener (Lee et al., 2017). It has been reported that the behavior of this connection or joint is affected by moisture and has a close relationship with the structural performance of timber buildings (Sjödin et al., 2004; Hong and Park, 2006). The effect of moisture cycling can be significant and should be taken into account in timber design when the timber structural members are exposed to cyclic moisture conditions (Svensson and Toratti, 2002; Chen et al., 2003; Awaludin et al., 2008; Guan and Rodd, 2001; $\mathrm{Xu}$ et al., 2009).

The objective of this study is to present research data about bending creep deflection according to the change of the relative humidity of glulam and bolted glulam under a load. In a room under the influence of an ambient relative humidity, glulams and bolted glulams were observed for approximately four years $(33,000 \mathrm{~h})$ under $20 \%$ and $30 \%$ stress levels, respectively. 


\section{MATERIALS and METHODS}

\subsection{Manufacture of Glulams and Bolted Glulams}

The seven layers of glulam were manufactured by using domestic larch (Larix kaempferi Carr.) laminae, which were dried to the point of having $11 \%$ to $12 \%$ moisture content and were not end jointed. Phenol-resorcinol-formaldehyde (PRF) was used as an adhesive (Kangnam Chemical, Seoul, South Korea), and the glue spread was set at $300 \mathrm{~g} / \mathrm{m}^{2}$ (single spread). The pressing pressure was set at $0.98 \mathrm{MPa}$. After being hardened for 24 hours, the specimens were cured at room temperature for one week. A total of 24 glulams were fabricated with a thickness of $175 \mathrm{~mm}$, a width of $130 \mathrm{~mm}$, and a length of $3500 \mathrm{~mm}$.

There were 12 glulams manufactured as bolted glulams, and 12 glulams manufactured as non-bolted glulams. Bolted glulam is a specimen fabricated by interconnecting two beams using steel gussets and bolts to expand the beam span. The center of each of the glulams manufactured with seven layers was cut, and a steel-gusset plate was inserted in the center of the beam, as shown in Fig. 1. The connecter was a steel-gusset plate with a thickness of $8 \mathrm{~mm}$, a width of $155 \mathrm{~mm}$, and a length of $460 \mathrm{~mm}$, and its bolts were $12 \mathrm{~mm}$ in diameter. At the center of each cut beam, the end distance of the bolt was $85 \mathrm{~mm}$, the distance of the bolt diameter was $7 \mathrm{~d}$ (d: bolt diameter), and the distance between the bolts was $95 \mathrm{~mm}$. The bolts of the four pieces were used at each side of the cut beams, and a total of eight bolts were used for connecting.

\subsection{Bending Test}

The glulams were subjected to a bending test by loading 4-point bending with a 2700-mm span and a 400-mm length between the load points. The bolted glulams were also subjected to a bending test after dividing the $2700-\mathrm{mm}$ span into three parts, each with a 900-mm load length. The load and deflection were then measured by using a data logger (TDS-303).

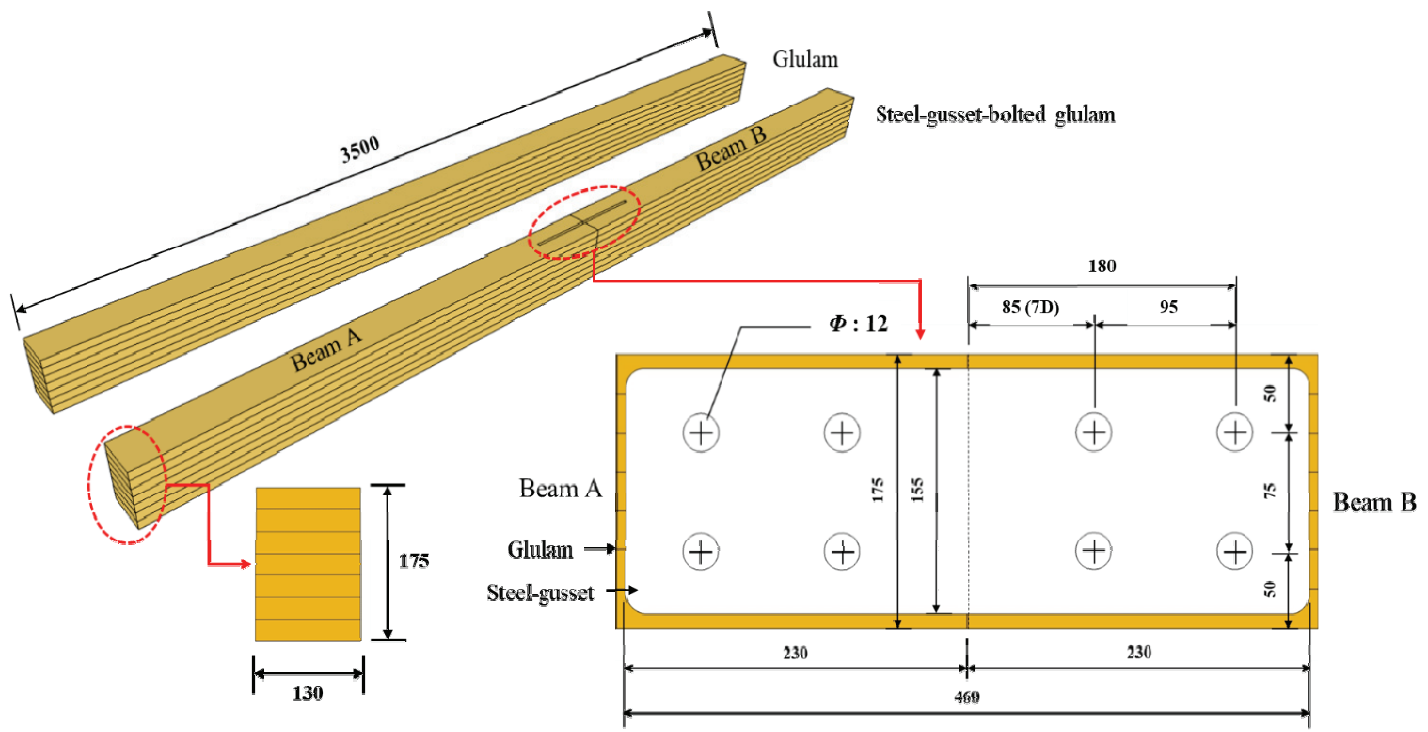

Fig. 1. The size of the glulam beams and the detailed diagram of the bolted glulam connection. 


\subsection{Creep Test}

Six glulams and six bolted glulams were used in the bending creep test. The geometrical moment of inertia of the glulam beams was $5.8 \times 10^{-5} \mathrm{~m}^{4}$. The span and load length in the creep test were the same as those in the bending test. The creep test was performed with the TDS 303 data logger every hour after a displacement transducer was placed at the center of each specimen. The modulus of rupture (MOR), which is the basic stress level, was calculated by using the mean of the 12 manufactured glulams. The creep de-

Table 1. Creep Test for the Physical Properties and Stress Level

\begin{tabular}{ccccc}
\hline \multicolumn{1}{c}{ Specimens } & MC (\%) & EI $\left(\mathrm{N} \cdot \mathrm{m}^{2}\right)$ & $\begin{array}{c}\text { Stress Level } \\
(\%)\end{array}$ \\
\hline \hline \multirow{5}{*}{ Glulam } & CON20-1 & 8.5 & 682784.4 & \\
& CON20-2 & 11.5 & 728303.3 & 20 \\
& CON20-3 & 8 & 768132.4 & \\
\cline { 2 - 5 } & CON30-1 & 10 & 660024.9 & \\
& CON30-2 & 10 & 728303.3 & 30 \\
& CON30-3 & 10.5 & 779512.2 & \\
\hline \multirow{4}{*}{$\begin{array}{c}\text { Bolted } \\
\text { glulam }\end{array}$} & Bolt20-1 & 12.5 & 722613.5 & \\
& Bolt20-2 & 10.5 & 768132.4 & 20 \\
\cline { 2 - 5 } & Bolt20-3 & 10.5 & 785202.0 & \\
& Bolt30-1 & 11.5 & 722613.5 & \\
& Bolt30-2 & 9.5 & 745372.9 & 30 \\
& Bolt30-3 & 10.5 & 773822.3 & \\
\hline
\end{tabular}

flection according to the changes in the temperature and relative humidity were measured after loading $20 \%$ and $30 \%$ of the load from the result of the bending strength (Table 1). The creep test was performed under the same conditions as when the 12 specimens were placed in a workshop whose humidity was significantly changed by opening and shutting the window. The relative humidity was measured every hour. The mean of the relative humidity was the mean of the values obtained from after the measurement to before the next measurement. Fig. 3 shows the method that was used for the creep testing under changing humidity. The creep test was performed for approximately 33,000 hours.

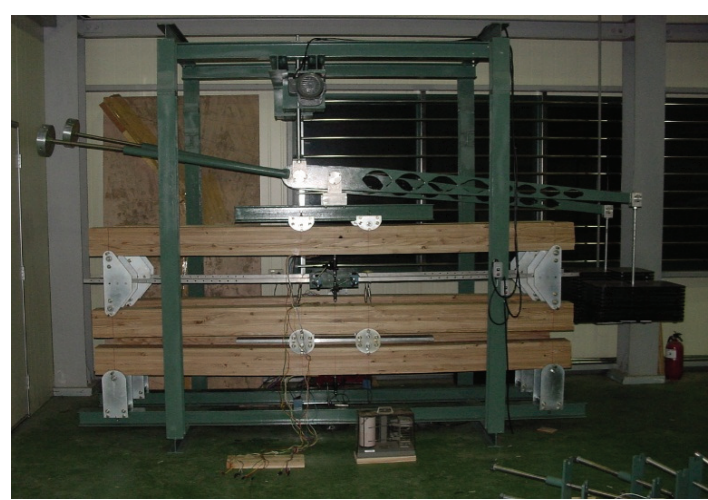

Fig. 2. Representation of the experiment.

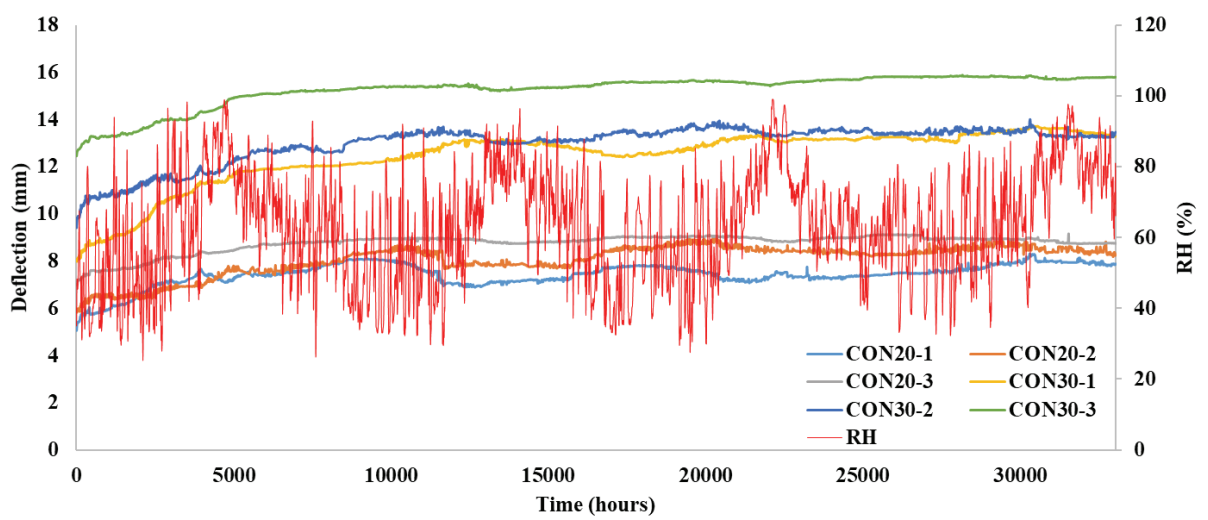

Fig. 3. Creep deflections of the glulams under relative humidity. 


\section{RESULTS and DISCUSSION}

\subsection{Creep Behaviors of Glulams}

As a result of the flexural strength tests for six glulams, the average MOR was measured at 50.0 MPa. Consequently, a stress of $10.0 \mathrm{MPa}$ (stress level of $20 \%$ ) was applied to the CON20 specimens and a stress of $15.0 \mathrm{MPa}$ (stress level of $30 \%$ ) was applied to the CON30 specimens.

The creep deflection of the glulams up to 33,000 hours is shown in Fig. 3. The creep deflection of the glulams up to 5,000 hours was deformed more by the load than by the temperature and relative humidity. After 5,000 hours, the creep deflection of the glulam was stabilized by loading, but the deflection progressed and was recovered by temperature and relative humidity. Fig. 4 shows a comparison of the relative humidity and relative creep of glulam CON20-2. The relative creep was affected by the load from the first spring to summer, and then stabilized and progressed slowly. The relative creep increased during the second autumn and winter, and recovered during spring and summer. The relative creep also increased during the third autumn and winter, and recovered during spring and summer. Deflection and recovery were repeated periodically as the temperature and humidity changed, and creep deflection progressed slowly.

Table 2 shows the relative creep that occurred every

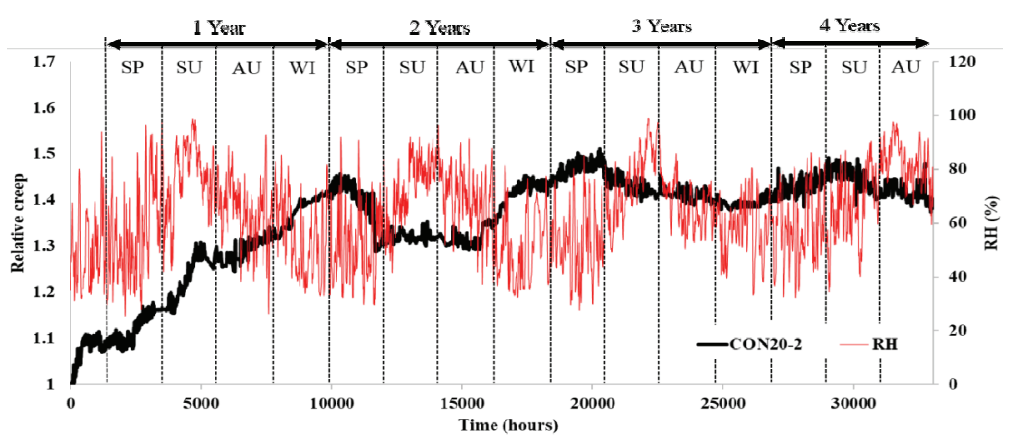

Fig. 4. Relationship between relative creep and relative humidity of typical specimens (CON20-2). SP: Spring (March-May); SU: Summer (June-August); AU: Autumn (September-November); and WI: Winter (December-February).

Table 2. Relative Creep of Glulam During Spring and Autumn

\begin{tabular}{|c|c|c|c|c|c|c|c|c|}
\hline \multirow{3}{*}{ Specimens } & \multicolumn{8}{|c|}{ Relative Creep $\left(C_{R}=\frac{\mu_{t}-\mu_{0}}{\mu_{0}}\right)$} \\
\hline & \multicolumn{2}{|c|}{1 Year } & \multicolumn{2}{|c|}{2 Years } & \multicolumn{2}{|c|}{3 Years } & \multicolumn{2}{|c|}{4 Years } \\
\hline & $\begin{array}{c}\text { SP } \\
(2,000 \mathrm{~h})\end{array}$ & $\begin{array}{c}\mathrm{AU} \\
(6,500 \mathrm{~h})\end{array}$ & $\begin{array}{c}\text { SP } \\
(11,000 \quad h)\end{array}$ & $\begin{array}{c}\mathrm{AU} \\
(15,000 \mathrm{~h})\end{array}$ & $\begin{array}{c}\text { SP } \\
(19,500 \quad h)\end{array}$ & $\begin{array}{c}\mathrm{AU} \\
(24,000 \mathrm{~h})\end{array}$ & $\begin{array}{c}\text { SP } \\
(28,500 \quad h)\end{array}$ & $\begin{array}{c}\mathrm{AU} \\
(33,000 \mathrm{~h})\end{array}$ \\
\hline CON20-1 & 1.32 & 1.48 & 1.52 & 1.44 & 1.49 & 1.44 & 1.52 & 1.55 \\
\hline CON20-2 & 1.07 & 1.26 & 1.41 & 1.29 & 1.49 & 1.42 & 1.42 & 1.39 \\
\hline CON20-3 & 1.13 & 1.25 & 1.28 & 1.27 & 1.30 & 1.29 & 1.28 & 1.26 \\
\hline CON30-1 & 1.21 & 1.49 & 1.57 & 1.61 & 1.60 & 1.65 & 1.68 & 1.67 \\
\hline CON30-2 & 1.20 & 1.34 & 1.44 & 1.39 & 1.46 & 1.44 & 1.44 & 1.41 \\
\hline CON30-3 & 1.10 & 1.21 & 1.24 & 1.23 & 1.26 & 1.26 & 1.27 & 1.27 \\
\hline Average & 1.17 & 1.34 & 1.41 & 1.37 & 1.43 & 1.41 & 1.44 & 1.42 \\
\hline
\end{tabular}

$C_{R}$ : Relative creep; $\mu_{t}$ : Deflection at time; $\mu_{0}$ : Initial deflection 
spring (1st, April) and autumn (1st, October). The relative creep increased to $1.17,1.34$, and 1.41 as the time increased to 11,000 hours during the second spring, but recovered to 1.37 during autumn of the same year. The relative creep increased to 1.43 during the third spring and recovered to 1.41 during autumn. In the creep deflections of the glulams, there was repeated deflection and recovery. After 33,000 hours, the relative creep of CON20-1, CON20-2, and CON20-3 were $1.59,1.39$, and 1.99 , respectively, and the relative creep of CON30-1, CON30-2, and CON30-3 were $1.67,1.41$, and 1.27 , respectively. These results were similar to the relative creep (1.6) of the glulam made from spruce as obtained in the preceding study (Ranta-Maunus and Kortesmaa, 2000).

\subsection{Creep Behaviors of the Bolted Glulams}

As a result of the flexural strength tests for six bolted glulams, the average MOR was measured at 13.3 $\mathrm{MPa}$. According to this result, a stress of $2.7 \mathrm{MPa}$ (stress level of 20\%) was applied to the Bolt20 specimens and a stress of $4.0 \mathrm{MPa}$ (stress level of 30\%) was applied to the CON30 specimens.

Fig. 5 shows the creep deflection of the bolted glulams up to 33,000 hours. For the creep deflection of the glulams, it changed abruptly after loading up to 5,000 hours, but stabilized after 5,000 hours, and then progressed until 33,000 hours. Fig. 6 shows a comparison of the relative humidity and the relative creep of bolted glulam Bolt30-2. For the creep deflection of the

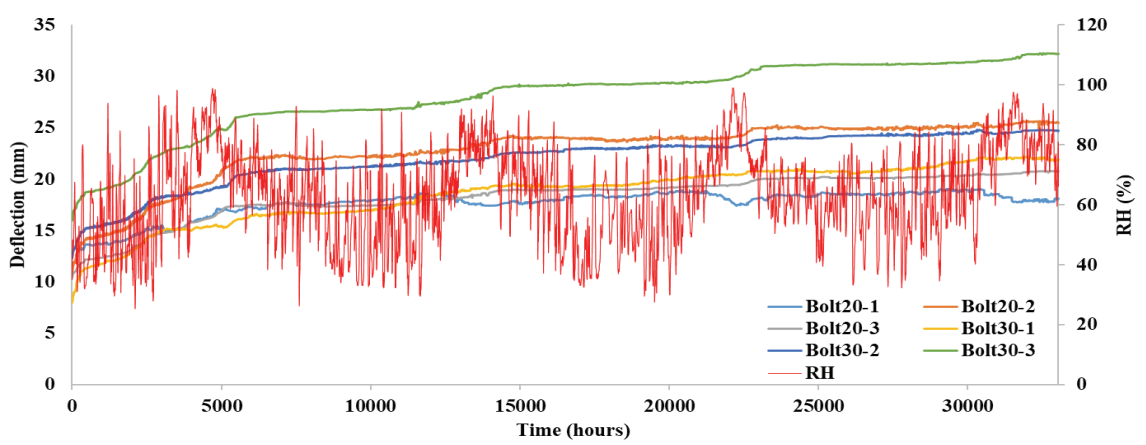

Fig. 5. Creep deflection of the bolted glulams under relative humidity.

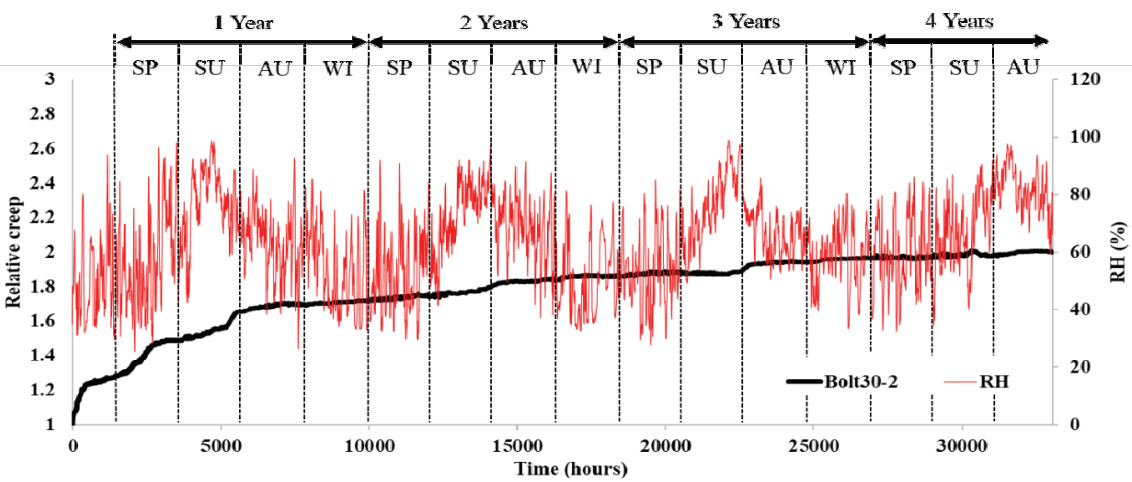

Fig. 6. Relationship between relative creep and relative humidity of typical specimens (Bolt30-2). SP: Spring (March-May); SU: Summer (June-August); AU: Autumn (September-November); and WI: Winter (December-February). 
glulams, the relative creep progressed through loading during the first spring and summer, and then stabilized and increased during the second autumn and winter. In contrast to the creep deflection of the glulams, the relative creep did not recover during spring and summer, but instead stabilized and then increased again during the following autumn and winter.

In the glulam connection, a high level of moisture movement occurs by the slot processing for steel plate insertion and the end grain of the members. It has also been reported that a significant change in the moisture content inside a member can result from direct exposure to outside air (Sjödin and Johansson, 2007). The existing research suggests that a change in relative humidity would alter the relative creep of the bolted glulam. However, the relative creep of the bolted glulams in this study showed a sharp increase in a short period of time as the relative humidity decreased between summer and autumn, and then stabilized until the next cycle. This trend reappeared every year. This is due to the fact that the steel plates and bolts in the connection area caused stress constraints by suppressing deformation induced by moisture in the wood, while the existence of the connection decreased the flexural stiffness of the glulam beam at the same time. In other words, the relative creep of the unconnected glulam in this study was more affected by a change of relative humidity than by a load, whereas the relative creep of the bolted glulam was more affected by a load than by relative humidity. The above two different causes that suppress the change in the relative creep of the bolted glulam or their combination are considered to cause a difference in the relative creep behavior between the glulam and the bolted glulam.

Table 3 shows the relative creep of the bolted glulams. The relative creep of Bolt20-2 from 6,500 hours (autumn) to 11,000 hours (spring) increased from 2.02 to 2.06 , but increased abruptly to 2.19 at 15,000 hours (autumn). The relative creep did not increase much (only to 2.21) during the following spring, but increased abruptly to 2.30 during autumn. The deflection of the bolted glulams increased slowly from autumn to spring, but changed significantly after summer. The relative creep increased 2.11 times on average after 33,000 hours. The creep deflection of the bolted glulams did not recover differently from that of the glulams, and the deflection progressed continually.

Table 3. Relative Creep of Bolted Glulam During Spring and Autumn

\begin{tabular}{|c|c|c|c|c|c|c|c|c|}
\hline \multirow{3}{*}{ Specimens } & \multicolumn{8}{|c|}{ Relative Creep $\left(C_{R}=\frac{\mu_{t}-\mu_{0}}{\mu_{0}}\right)$} \\
\hline & \multicolumn{2}{|c|}{1 Year } & \multicolumn{2}{|c|}{2 Years } & \multicolumn{2}{|c|}{3 Years } & \multicolumn{2}{|c|}{4 Years } \\
\hline & $\begin{array}{c}\mathrm{SP} \\
(2,000 \mathrm{~h})\end{array}$ & $\begin{array}{c}\mathrm{AU} \\
(6,500 \mathrm{~h})\end{array}$ & $\begin{array}{c}\text { SP } \\
(11,000 \quad h)\end{array}$ & $\begin{array}{c}\mathrm{AU} \\
(15,000 \mathrm{~h}) \\
\end{array}$ & $\begin{array}{c}\text { SP } \\
(19,500 \mathrm{~h})\end{array}$ & $\begin{array}{c}\mathrm{AU} \\
(24,000 \mathrm{~h})\end{array}$ & $\begin{array}{c}\text { SP } \\
(28,500 h)\end{array}$ & $\begin{array}{c}\mathrm{AU} \\
(33,000 \mathrm{~h})\end{array}$ \\
\hline Bolt20-1 & 1.30 & 1.53 & 1.62 & 1.58 & 1.67 & 1.64 & 1.65 & 1.59 \\
\hline Bolt20-2 & 1.47 & 2.02 & 2.06 & 2.19 & 2.21 & 2.30 & 2.27 & 2.34 \\
\hline Bolt20-3 & 1.30 & 1.67 & 1.68 & 1.82 & 1.84 & 1.93 & 1.94 & 1.99 \\
\hline Bolt30-1 & 1.65 & 2.06 & 2.19 & 2.41 & 2.47 & 2.61 & 2.63 & 2.74 \\
\hline Bolt30-2 & 1.36 & 1.68 & 1.74 & 1.83 & 1.89 & 1.94 & 1.96 & 2.01 \\
\hline Bolt30-3 & 1.29 & 1.65 & 1.68 & 1.82 & 1.83 & 1.94 & 1.95 & 2.01 \\
\hline Average & 1.39 & 1.77 & 1.83 & 1.94 & 1.99 & 2.06 & 2.07 & 2.11 \\
\hline
\end{tabular}

$C_{R}$ : Relative creep; $\mu_{t}$ : Deflection at time; $\mu_{0}$ : Initial deflection 


\subsection{Discussion}

The variation in the creep deflection of glulam with relative humidity was greater than that of the bolted glulam. Between the relative humidity and the creep deflection of glulams, the tendency was close to the inverse behavior. In the case of the bolted glulam, an inverse behavior was observed with the relative humidity as creep deflection increased, but in contrast with the bolted glulam, the creep deflection did not recover, but instead remained stable and tended to increase again. It was confirmed that the larger the bending rigidity of the glulams, the more positive the effect it has on the relative creep and stabilization of creep. However, in the case of the bolted glulam, these tendencies were not significant.

The applied stress level affected the creep deflection of glulam. At 33,000 hours, the average relative creep values of glulam were 1.4 (stress level of 20\%) and 1.45 (stress level of $30 \%$ ). In particular, the average relative creep values of bolted glulam were 1.97 and 2.25 , respectively, which exhibited more effect from the stress level than the glulam. Bolted glulam showed a repetitive increase and stability of the relative creep, unlike glulam, which had a repetitive increase and recovery of the relative creep. In addition, the bending rigidity of the bolted glulam did not significantly affect the resistance of creep deflection, which increased as the stress level increased. Eventually, after 33,000 hours, the relative creep of the bolted glulam was $49 \%$ higher than that of the glulam. These results indicate that the beam-to-beam connection of glulam is a factor in the deterioration of the bending creep performance and the need for further studies on the reinforcement of the connection.

\section{CONCLUSION}

In this study, the behavior of the creep deflection of glulam beams and steel-gusset-bolted glulam beams was examined under relative humidity variation.

1. The relative creep of the glulams was affected by loading until 5,000 hours. After 5,000 hours, their relative creep was stabilized by loading, but the relative creep progressed, and then recovered by the temperature and relative humidity.

2. After 33,000 hours, the relative creep of the CON20 series increased by $39 \%$ to $99 \%$, and the relative creep of the $\mathrm{CON} 30$ series increased by $27 \%$ to $67 \%$, as compared with instantaneous elastic deflection. The relative creep increased during autumn and winter, and the relative creep recovered during spring and summer.

3 . The relative creep of the bolted glulams changed abruptly by loading up to 5,000 hours, but stabilized after 5,000 hours, and then gradually increased until 33,000 hours.

4. In the case of the bolted glulam, a rapid increase in relative creep occurred after summer, but the increase was moderate and steady. As a result, the relative creep of the bolted glulam increased 2.11 times after 33,000 hours, which was 49\% higher than that of the glulam.

\section{ACKNOWLEDGMENT}

This study was supported by 2017 Research Grant from Kangwon National University (No. 520170358).

\section{REFERENCES}

Aratake, S., Morita, H., Arima, T. 2011. Bending creep of glued laminated timber (glulam) using sugi (Cryptomeria japonica) laminae with extremely low Young's modulus for the inner layers. Journal of Wood Science 57(4): 267-275.

Awaludin, A., Hirai, T., Hayashikawa, T., Sasaki, Y. 2008. Load-carrying capacity of steel-to-timber joints with a pretensioned bolt. Journal of Wood 
Science 54(5): 362-368. https://doi.org/10.1007/ s10086-008-0962-8

Bengtsson, C. 2001. Mechano-sorptive bending creep of timber-influence of material parameters. Holz als Roh-und Werkstoff 59(4): 229-236.

Bengtsson, C., Kliger, R. 2003. Bending creep of hightemperature dried spruce timber. Holzforschung 57(1): 95-100. https://doi.org/10.1515/HF.2003.015

Byeon, J.W., Kim, T.H., Yang, J.K., Byeon, H.S., Park, H.M. 2017. Bending creep property of crosslaminated woods made with six domestic species. Journal of the Korean Wood Science and Technology 45(6): 689-702.

https://doi.org/10.5658/WOOD.2017.45.6.689

Chen, C.J., Lee, T.L., Jeng, D.S. 2003. Finite element modeling for the mechanical behavior of doweltype timber joints. Computers \& Structures 81(3031): 2731-2738. https://doi.org/10.1016/S0045-7949(03)00338-9

Epmeier, H., Johansson, M., Kliger, R., Westin, M. 2007. Bending creep performance of modified timber. Holz als Roh-und Werkstoff 65(5): 343-351.

Guan, Z., Rodd, P. 2001. DVW-Local reinforcement for timber joints. Journal of structural engineering 127(8): 894-900. https://doi.org/10.1061/(ASCE) 0733-9445(2001)127:8(894)

Hong, S.I., Park, J.C. 2006. Studies on evaluation for long-term structural performance of pinus densiflora Sieb. Et Zucc. ( I ): Shear creep and mechanosorptive behavior of drift pin jointed lumber. Journal of the Korean Wood Science and Technology 34(5): 11-18.

Hunt, D.G. 1999. A unified approach to creep of wood.
Proceedings of the Royal Society of London. Series A: Mathematical, Physical and Engineering Sciences 455(1991): 4077-4095.

Lee, I.H., Song, Y.J., Hong, S.I. 2017. Evaluation of the moment resistance of reinforced wooden gusset to glulam joint. Journal of the Korean Wood Science and Technology 45(1): 53-61.

O'Ceallaigh, C., Harte, A., Sikora, K., McPolin, D. 2014. Mechano-sorptive creep of FRP reinforced laminated timber beams. Civil Engineering Research in Ireland, CERI 2014. Queen's University Belfast, 28-29 August 2014.

Ranta-Maunus, A., Kortesmaa, M. 2000. Creep of timber during eight years in natural environments. In World Conference on Timber Engineering. Whistler, CA, Vol. 31.

Sjödin, J., Johansson, C.J. 2007. Influence of initial moisture induced stresses in multiple steel-totimber dowel joints. Holz als Roh-und Werkstoff 65(1): 71-77.

Sjödin, J., Johansson, C.J., Petersson, H. 2004. Influence of moisture induced stresses in steel-to-timber dowel joints. In Proceedings of the 8th world conference on timber engineering WCTE.

Svensson, S., Toratti, T. 2002. Mechanical response of wood perpendicular to grain when subjected to changes of humidity. Wood Science and Technology 36(2): 145-156.

Xu, B.H., Taazount, M., Bouchair, A., Racher, P. 2009. Numerical 3D finite element modelling and experimental tests for dowel-type timber joints. Construction and Building Materials 23(9): 3043-3052. https://doi.org/10.1016/j.conbuildmat.2009.04.00 